\title{
JUDICIAL REVIEW OF CRIMINAL DEFAMATION \\ ACCORDING TO THE LAW OF ELECTRONIC INFORMATION AND \\ TRANSACTION: A CASE STUDY OF FLOURENCE SAULINA SIHOMBING
}

\author{
Dyah Rosiana Puspitasari \\ Universitas Proklamasi 45 Yogyakarta \\ Email: rosianabot@gmail.com
}

\begin{abstract}
This study analyses defamation via social media towards Flaurence Saulina Sihombing case. The study raises the elements of contempt in Law Number 11 of 2008 which was converted into Law Number 19 of 2016 con Electronic Information and Transactions (EIT) and compare it with the humiliation under the Criminal Code. The purpose of this study was to determine whether the prosecution on Florence Saulina Sihombing meet the elements of contempt in accordance with the prohibited stipulation under Article 27 paragraph (3) Electronic Information and Transactions Law. This research using normative juridical approach. The source of the data is secondary data source that the data obtained from the literature by studying three legal materials, namely: primary legal materials, secondary legal materials, tertiary legal materials that will be classified and systematized. The conclusion shows that the case Flaurence Saulina Sihombing meet a subjective element in the form of intentionally actions. This actions undertaken by Florence met the element strike action. The object in the form of honour based on Article 27 Law Number 11 of 2008 which was converted into Law Number 19 of 2016 on Electronic Information and Transactions (EIT). The writer tends to confirmly agree with the Yogyakarta District Court via Decision Number 382/Pid.B/2014/PN Yyk of 2015.
\end{abstract}

\section{Keyword: Affronts, Law of Electronic Information and Transactions (EIT), Flourence}

\section{Saulina Sihombing case}

\section{A. INTRODUCTION}

Freedom of speech in public has been regulated in the 1945 Constitution of the Republic of Indonesia, especially in article $28 \mathrm{E}$ and $28 \mathrm{~F}$. Public opinion means expressing opinions either orally or in writing directly or through social media in electronic devices. The various types of social media today is a positive impact of technological development, where the development of information technology today is a double-edged sword, because in addition to contributing to the improvement of welfare, progress and human civilization, as well as a means of negative impact of action against the law (Widyapramono, 1998: 191).

(C) 2017; This is an Open Access Research distributed under the terms of the Creative Commons Attribution Licensee (https://creativecommons.org/licenses/by/4.0), which permits unrestricted use, distribution, and reproduction in any medium, provided the original work is properly cited. 
Problems regarding freedom of speech through the electronic media governed in law number 11 of 2008 on Electronic Information and Transactions (EIT) which has been amended into Law Number 19 of 2016 Article 27 paragraph (3), namely insult or defamation through social media as in the case of Flaurence Saulina Sihombing against the city of Yogyakarta charged with Article 27 paragraph (3) Jo Article 45 paragraph (1) and Article 28 paragraph 2 Jo Article 45 paragraph (1) Law Number 11 of 2008 on Electronic Information and Transactions (EIT), which has been converted into Law Number 19 of 2016 is one example that our speech through social media should still be considered good or bad.

Insult or defamation through social media is essentially an act that attacks a person's good name or honor which is not in a sexual sense so that the person feels harmed via electronic social media. Honor and good name have different understanding, but both are related. When a person attacks honor will result in honor and good reputation tainted, so when a person's good name is attacked then his honor is also polluted. Therefore, attacking one of the honor or reputation of a person is enough to justify an accusation.

\section{B. PROBLEM STATEMENT}

Based on the introduction above, the problems can be stated in this paper is whether the prosecution of Florence Saulina Sihombing meet the elements of criminal defamation According to the Law of Electronic Information And Transactions?

\section{RESEARH METHODS}

This writing starts from the planning stage (preparation), followed by the implementation stage, and ends with the writing of the report writing phase. The method of approach used in this paper is the normative juridical method, namely the approach that uses the concept of positivist legis which states that the law is synonymous with the written norms created and promulgated by the institutions or officials authorized (Ronny Hanitijo Soemitro, 1988: 11). Besides this concept also viewed the law as a normative system that is autonomous, closed and regardless of community life. While the method of collecting the legal material is done by separating between primary law material and secondary law material. 


\section{RESEARCH RESULT AND DISCUSSION}

\section{Definition Of Contempt}

According to R Susilo in the explanation of Article 310 of the Criminal Code, explains that, "insult" is "attacking the honor and reputation of a person". The attacker usually feels "ashamed" of "Honor" who is attacked here only about the honor of the "good name", not the "honor" in the sexual field, the honor that can be defamed by offended members of his genitals in the sphere of sexual lust (R. Soesilo : 225).

A connection between honor and good name in terms of insult, can be seen from their respective understanding. Honor is the feeling of honor of a person in the eyes of society, where everyone has the right to be treated as a respected member of society. Attacking honor means doing deeds according to judgment generally affects a person's honor. Respect and deeds that fall into the category of attacking the honor of a person are determined according to the community environment in which the act is performed (Mudzakir, 2004: 17). Humiliation is seen from 2 kinds, namely insults verbally, and written insults. In his book, Oemar Seno Adji states the humiliation is known as insult, which is divided into the following (Oemar Seno Adji, , 1990: 37):

a. Material Humiliation

The contempt that consists a fact which includes an objective statement in words orally or in writing, then the determining factor is the content of statement that are used in writing and oral.

b. Formal Humiliation

In principle, the contempt is set forth in Chapter XVI of the Criminal Code contained in Articles 310 to 321 of the Criminal Code. Looking at the explanation of R. Soesilo in Article 310 of the Criminal Code, we can see that the Criminal Code divides six kinds of humiliation, namely:

1. Sacrilege;

2. Libel;

3. Slander;

4. Mild humiliation; 
5. False complaints or slander complaints.

\section{Special Forms Of Contempt}

Special forms of humiliation can be seen in Article 142 of the Criminal Code on insult to the head of the foreign countries; Articles 143 and 144 of the Indonesian Criminal Code on humiliation against representatives of foreign countries in Indonesia; Article 154a of the Indonesian Criminal Code concerning insult of the Indonesian national flag and the emblem of the Republic of Indonesia; Article 142a of the Criminal Code concerning defamation of the national flag of another country; Article 156 and 157 of the Criminal Code on defamation against certain population groups in Indonesia; (Articles 207 and 208 of the Criminal Code on defamation against the authorities or legal entities; (Article 156a, Article 177 point 1 and 2 of the Criminal Code on defamation in matters relating to religion.

\section{Definition Of Cyber Law}

The meeting between the communication network system and information technology is known as Telematics. Telematics itself comes from the French "Telematique". Information Technology is used to explain the processing of information systems to support information systems within an organization for customers and suppliers, also understood as a technology that capable to storing, transmitting and processing information and communication (Danvianto Budhijanto, 2013: 257). Another term of telematics is the new hybrid technology that is the integration between telecommunication technology and informatics. Even in its development the media becomes an integral part of the definition of telematics as a unity of convergence (Maskun, 2013: 1).

\section{Legal Framework Of Telematics}


The birth of regulations that provide guidance to the public in cyberspace is absolutely necessary. In Indonesia this norm is contained in Law Number 11 of 2008 on Electronic Information and Transactions (EIT), which was enacted on 21 April 2008. This is due to widespread misuse in the field of telematics. in Indonesia, the legal framework of telematics law has several elements:

a. Criminal Law

One of the impacts of the development of telematics activities today that is inevitable is the emergence of types of abuse using computer media into new crimes associated with services and electronic transactions.

b. E-Commerce Law

Electronic commerce or e-commerce is a common type of trading today. Ecommerce is a combination of electronic funds transfer, electronic data exchange, electronic marketing, or online marketing and automated data storage systems.

c. Consumer Protection Law

In trade transactions known the existence of the seller and the buyers or providers of goods and services and consumers. In terms of the utilization of goods and services provided by the service provider should provide satisfaction for the audience in this case Consumers.

d. Telecommunications Law

Communication is one manifestation of the life of man as a social being. In Indonesia, communication is regulated in Law Number 36 of 1999 on Telecommunication that aims to be orderly and secure for all users of communication technology, and protect the interests and security of the country.

e. Intellectual Property Rights

Related to Intellectual property Rights (IPR), at the end of the year 2000 has passed three new Laws in the field of intellectual property rights, namely :

1) Law Number 30 of 2000 on Trade Secret

2) Law Number 31 of 2000 on Industrial Design, and

3) Law Number 32 of 2000 on Layout Designs of Integrated Circuits. 
5. The Electronic Information and Transactions Law

The need to overcome the bad possibilities of technological advancement which encourages the Government of Indonesia to instituted a rule that is supposed to be an electronic transaction guidelines and as a legal certainty for the community, namely Law No. 11 Year 2008 that had been converted into Law Number 19 of 2016 on Electronic Information and Transactions (EIT). The birth of the EIT Law is an enrichment of the legal fields as an influence of technological developments and globalization. So if there are disputes and violations that cause losses and even victims in cyber space can be solved by the birth of this EIT Law.

\section{Criminal Contempt Under The Electronic Information and Transactions Law}

The Criminal Law of Contempt in the EIT Law as outlined in Article 27 paragraph (3) formulates:

"Any person who deliberately and without rights distribute and/or transmit and/or make an accessible Electronic Information and/or Electronic Documents which have a charge of contempt and/or defamation"

Law Number 11 of 2008 does not affirm the provision stating that Article 27 paragraph (3) of the EIT Law is a complaint offense, it is often disputed in applying this provision. However, the Constitutional Court Decision Number 50 / PUU-VI / 2008 regarding the constitutionality of Article 27 paragraph (3) if there is a complaint submitted to the police and only the victim must make a complaint to the police so that the case can be processed.

In 2016, there are changes from the Law Number 11 of 2008 into Law Number 19 of 2016, in which there are some changes including to Article 27 paragraph (3) which added the explanation of the terms distribute, transmit and/or make accessible Electronic Information. The meaning of distribute here is to transmit and / or disseminate Electronic Information and / or Electronic Documents to many persons or parties through the Electronic System. While the meaning of word transmits is to send Electronic Information and / or Eletronic Documents addressed to one party via Electronic Systems. Further "making accessible" means all other acts other than distributing and transmitting 
through Electronic Systems that cause Electronic Information and / or Electronic Documents to be known to others or the public. Law Number 19 of 2016 has confirmed that the provision is a complaint offense not a general offense. It is also emphasized that the criminal element in the provision refers to the defamation and libel provisions regulated in the Criminal Code.

\section{The Results And Discussion}

In relating to the crime of defamation contained in the Criminal Code, Adami Chazawi explains the elements in Article 310 of the Criminal Code are as follows (http://www.negarahukum.com/hukum/delik-penghinaan.html):

a) The subjective in the form of intent

In slander crime there are two elements of error, namely opzettelijk and intent or purpose. Although in doctrine, that intention is also deliberate (in the narrow sense), which is called intentional purpose. However, the function of intentional elements and elements of intent in slander are different. Inner attitude is "deliberately" aimed at the act of attacking the honor or the good name of the person (deeds and objects of deeds). While the attitude of the inner "intent" aimed at the element of "known by the public" about the act of what is alleged on that person. Then the elements covered by the accident are the following elements:

1) Acts of attack;

2) The object is the honor or reputation of the person;

3) By accusing a particular act.

b) The act of attacking

The act of attacking (aanranden), is not physical, because against what is attacked (the object) is not physical but feelings about honor and feelings about people's good name.

c) The object is the honor or reputation of the person

The object to be attacked is the sense / feeling of self-esteem regarding the honor (eer), and the sense / feeling of self-esteem regarding the person's good name (goedennaam). The sense of self-worth is the essence of the object of every insult, 
which according to Wirjono Projodikoro is to make the measure of humiliation. The sense of self-worth in humiliation is a sense of honor in the field of honor, and a sense of self-worth in the field of good name.

d) By accusing a particular act

Above has been explained that the act of attacking is aimed at the sense of self-worth or the dignity of the person, by using the word / phrase through speech, the way by accusing a certain act. So the thing that alleged the maker must be a certain deed, and not other things for example to refer to someone with words that are impolite and others.

If you want to see the element of humiliation are set in the EIT Law, it must also be seen the criminal provisions set forth in the Criminal Code regarding contempt. In principle any criminal act committed by a person must meet the elements contained in each article in the Criminal Code, namely: The subjective element is intentional and intent; Attacking; The object is the honor and good name of the person; By accusing certain acts, and supported by the elements contained in Article 27 paragraph (3) Electronic Informations and Transactions Law.

The explanation submitted by Adami Chazawi related to insults when associated with the case of Florence Saulina Sihombing and referring to the provisions set forth in Article 27 paragraph (3) of Law Number 11 of 2008 which has been amended to Law Number 19 of 2016 Electronic Information and Transactions can be summarized as follows:

a) The subjective in the form of intentional and intent

When looking at the chronological case as mentioned above, the humiliation committed by Florence to the citizens of Yogyakarta would have fulfilled the subjective elements of "deliberate" and "intent". The "deliberate" inner attitude of Florence has led to the act of attacking the honor and and the reputation of others, this is indicated by the words issued by Florence is degrading to others, especially the citizens of Yogyakarta. While the inner attitude of "intent" is aimed at the "known by the public" element of what the alleged person accused is also proven, as it can be seen from the social media of Florence. 
Another argument was put forward by Florence's Legal Counsel who stated that these words were excluded or written by Florence in her Path, so that the "known by the public" element is not proved because it is still private, whereas the author has different arguments. The author assumes that the words issued or written by Florence in her Path already fulfill the element "known by the public", because those who know the words are not only one person, but more than one so is plural common.

Another thing the author needs to say is "friendship" in social media, including the path, not eliminating the status of "known by the public", because friendships in social networking is mere morality that does not diminish the rights and duties of someone reporting the crime to Police. In addition, Florence forgot the "make accessible" clause contained in Article 27 paragraph (3) of the Electronic Information and Transactions Law, so even though Florence argued not to spread insulting words to the citizens of Yogyakarta, in fact there were those who could access the insult. Unfortunately, the Electronic Information and Transactions Law does not explain in detail what it "distributes", "transmits", and "makes accessible" so that each party has the right to interpret the existing rules.

b) The act of attacking

The deed made by Florence has fulfilled the second element, the "act of attacks". The attack is clearly not done to the physical citizens of Yogyakarta, but to his feelings and honor. It was seen from there is no evidence that leads to the act of physical assaults, both during the investigation at the police until the examination at the trial. Therefore, it would be appropriate that the allegation addressed to Florence is a criminal offense.

Based on the above description, there have been efforts to make peace between the complainant and reported party, but the attempt failed because the complainant felt the reported (Florence) did not show good faith for peace. It is certainly not helping the atmosphere at once the hurt feelings of the people of Yogyakarta, especially the status of the Florence Sihombing is a "guest" in Yogyakarta. In fact, the supposed criminal acts committed by the Florence can be 
solved by way of kinship, given the provisions in Article 27 paragraph (3) Electronic Information and Transactions Law is a complaint offense:

c) The object is the honor or reputation of the person

After seeing the "act of attack", then what should be seen next is the object being attacked. In the case of Florence, it is clear that the object being attacked is the honor and dignity of the citizens of Yogyakarta, as well as the background of reporting by the citizens of Yogyakarta, through NGO (Jati Suara), to the police. Florence was accused of spreading hatred against Yogyakarta as well as vilifying Yogyakarta, while Florence was currently studying in the city of Yogyakarta.

To examine the opinion expressed by Wirjono Projodikoro that self-esteem is the essence of every insult and a measure of humiliation. In relation to the case, in principle only the citizens of Yogyakarta are entitled to assess whether what is done by Florence is enough to injure the dignity, honor and good name of the people of Yogyakarta or not. However, the authors argue that what is done by Florence already injurious self esteem and honor someone, because Yogyakarta and its citizens are not as similar as to what accused by Florence.

d) By accusing a particular act

Above has been explained that the act of attack is aimed at the sense of selfworth or dignity of people, by using words / sentences through speech and writing, how to accuse a particular act. This element is fulfilled because Florence alleges that Yogyakarta is "poor", "dumb", and "uncultured" and much more scorn by Florence. Of course this is not in accordance with reality, considering Yogyakarta is a student city and has so many customs, cultures and traditions.

Based on the above, the authors agree with the criminal decision issued by the judge of the Yogyakarta District Court through Decision Number 382 / Pid.B / 2014 / PN Yyk of 2015 has dropped the verdict that reads:

Judge: The Defendant FLORENCE SAULINA SIHOMBING, has been proven legally and convincingly guilty of committing a criminal offence INTENTIONALLY AND WITHOUT RIGHT DISTRIBUTING ELECTRONIC INFORMATION THROUGH the TELECOMMUNICATION NETWORK WHICH CONTAINS INSULT AND SLANDER, as in the alternative charges number one; 2) punish the defendant therefore by imprisonment for 2 (two) months, and a fine of Rp. 
10.000.000, - (ten million rupiahs) on the condition that if the fine is not paid will be replaced with imprisonment for 1 (one) month; 3) stipulates that the crime shall not be lived unless in the future there is a decision of another judge that determines otherwise because the convicted person commits a crime before the trial period of 6 (six) months ends; 4) establishing evidence in the form of 1 (one) iPhone 5c brand mobile phone imei number 358031058309538; 1 (one) sim card with the number 082160685742 returned to the Defendant Florence Saulina Sihombing; one (1) sheet of screen capture of Florence's Path; one (1) sheet of screen capture of Florence Saulina Sihombing's Twitter; 2 (two) sheets of the screen capture of Florence's Path; one (1) sheet of screen capture of Florence Saulina Sihombing's Twitter; 2 (two) sheets of screen capture Florence's Path remains enclosed in the case file; charge a Defendant to pay court costs in this case amounted to Rp. 5.000,- (five thousand rupiah),

\section{E. CLOSING}

Advance on information technology today has a positive impact of providing human convenience to obtain information, accelerate economic progress, provide a broad space to express opinions. In addition to positive impacts there are also negative impacts, including emerging types of new criminal acts using social media on the internet. To overcome the possibility of negative impacts presented by advances in information technology is the establishment of rules to regulate such matters as outlined in Law Number 11 of 2008 has been changed to Law Number 19 of 2016 on the Electronic Information and Transactions (EIT). Related to the cases of contempt by Florence Saulina Sihombing, can get to the court because of the absence of reports from NGOS and mass organizations who feel disturbed by the behaviour of Florence Saulina Sihombing in social media. This case has been decided in the Court of Yogyakarta, through the Decision Number 382/Pid.B/2014/PN Yyk of 2015,with the demands submitted to Florence Saulina Sihombing has met the elements stipulated in the Law Number 11 of 2008 which has been converted into Law Number 19 of 2016 on Electronic Information and Transaction, so that the verdict handed down by the judge has appropriate.

\section{BIBLIOGRAPHY}

\section{Books:}

Danvianto Budhijanto, 2013, Hukum telekomunikasi, Penyiaran dan Teknologi Informasi Regulasi dan Konvergensi (Telecommunication Law, Broadcasting and Information Technology Regulation and Convergence). Bandung: PT. Refika Aditama, 
Oemar Seno Adji, 1990, Perkembangan Delik Pers di Indonesia (Development of Press Release In Indonesia), Jakarta: Erlangga,

R. Soesilo, Kitab Undang-Undang Hukum Pidana (KUHP) Serta Komentar-Komentarnya Lengkap Pasal Demi Pasal (Book of Criminal Law (KUHP) and Its Complete Comments), Bogor: Politeia

Ronny Hanitijo Soemitro, 1988, Metode Penulisan Hukum dan jurimetri (Legal Writing Methods and Jurimetry), Jakarta: Ghalia Indonesia,

Maskun, 2013, Kejahatan Siber Cybercrime Suatu pengantar, Jakarta: Kencana,

Mudzakir, 2004, Delik Penghinaan dalam Pemberitaan Pers Mengenai Pejabat Publik, Dictum 3, Jakarta: Sinar Grafika,

Widyapramono, 1998, Kejahatan di bidang Komputer, Jakarta: Pustaka Sinar Harapan,

\section{Regulations:}

The Criminal Code

Law Number 11 of 2008 on Electronic Information and Transactions, State Gazette of The Republic of Indonesia Number 58 of 2008

Law Number 19 of 2016 on Amendment of Law No. 11 Year 2008 on Electronic Information and Transactions, State Gazette of The Republic of Indonesia Number 19 of 2006

\section{Website:}

http://www.negarahukum.com/hukum/delik-penghinaan.html accessed on October 28, 2016 